\title{
Editor's Note on This Special Issue
}

\section{The 2021 Celebration of African and Asian Studies!}

I was very much enthused when Elizabeth You informed me about this celebration and the events related to it.

With this special issue (number 1 and 2) of 2021 on Chinweizu, one of the most brilliant critical minds of our time, we have produced 20 volumes of African and Asian Studies since 2002. This celebration coincides with the request made by Professor Lloyd Amoah of the University of Ghana in which he expressed an interest to work on a special issue on Mwalimu Chinweizu. It is almost as though this was perfectly planned. Chinweizu is a public intellectual with an exceptional interdisciplinary, multidisciplinary and comparativist scholarship, who has made a significant contribution in the studies of Africa, Europe and Asia.

The journal is well-established in the peer-reviewed social science arena with interdisciplinary and multidisciplinary intellectual perspectives. It publishes original research articles using either comparative scopes of analysis or single articles or case studies. In any case, articles must be intellectually, historically and sociologically localized within African and Asian geo-politics.

I was invited by the Brill editor to become the Editor-in-Chief of African and Asian Studies in 2002. At that time, I was co-editor of the International Journal of Comparative Sociology since 1998. The journal was published by Brill. During that time, I worked alongside Shivu Ishrawaran, John Burton, and Masamichi Sasaki. For a few years after that invitation, I was involved in both journals at the editorial level.

This year, 2021, Brill is celebrating the production of 20 volumes of African and Asian Studies without any interruption. The producers and members of our communities recognize this monumental work and professional commitment. Each volume contains 4 issues, and each issue has between 6 and 9 articles.

Every year since 2002, I have also been publishing a special issue, (1 and 2 numbers). The special issue has focused on a specific topic or theme as defined by a team of scholars working on a research project for which they wish to publish their scholarship collectively. The team has a leader or leaders who are called the guest-editors who are in charge of coordinating the works 
with me until their articles become publishable and are published. This also means that I have published 20 special issues, including the 2021's one.

In terms of scholarship, the team members have been mostly from Africa, Asia, and their Diasporas. They come from either single disciplinary or from multidisciplinary perspectives and backgrounds.

I have been lucky to be working with interdisciplinary and multidisciplinary members of the editorial board whom I have been selecting based on their intellectual interests, their particular contributions to the journal and the needs of the journal. In this work, we also invite independent scholars to review submissions. I have a Managing Editor, Juliana S. Klitgaard-Ellis, who works like a liaison officer between the authors, potential authors, myself, Lloyd Cabasag, the Journal Project Manager, Elizabeth You, the Assistant Editor Asian Studies, Dr. Qin Higley, Senior Acquisition Manager - Asian Studies, and the whole EM Team.

Professor A.B. Assensoh and Professor Yvette M. Alex-Assensoh are more than the co-editors of the book reviews, as they have been also recruiting the reviewers and the authors/writers as well. Over the years, they have produced an impressive number of book reviews.

In celebrating the achievements of the journal, I selected 20 articles, which I considered to be most representative of what we have been publishing. These articles are available online to scholars, researchers and public figures who might be interested in our publications.

My deep gratitude goes to all of them. Together this peer-review journal has been producing a rigorous scientific body of knowledge needed for the progress of the academia and the humanities.

I also very much thank the Guest Editors Lloyd G. Adu Amoah and Lawrence Ogbo Ugwuanyi for putting together an issue (1 and 2) on "Chinweizu: Over Forty Years of Reflections on Africa, Asia and the World," which methodologically and paradigmatically reflects what we have been doing in this journal: to study critically and comprehensively Africa and Asia in various forms and from different perspectives. In this special issue, the authors interrogate Chinweizu's thoughts and his views on women, science and technology, the complexity of Africa in the world system, Africa's cultural diversity, her sociology, languages, her scientific and technological foundation, her relationship with Asia and the prospects of the future.

I invite scholars who are collectively working on any topic or theme to submit their abstracts for special issues. The number of authors for any special issue is between 7 and 10 . 
I invite all the authors, past and new, and members of the editorial board and all who are interested in our work to join us celebrate the long life for the journal and its immense contribution towards the development and appreciation of social sciences, the humanities and the arts and their policy implications.

Congratulations to all, and let's celebrate this together!

Tukumbi Lumumba-Kasongo

Editor-in-Chief

African and Asian Studies 